\title{
Nutritional Characteristics of Biochar from Pineapple Leaf Residue and Sago Waste
}

\author{
Norshidawatie Bohari ${ }^{1,2}$, Hasmah Mohidin ${ }^{1,2 *}$, Juferi Idris ${ }^{3,4}$, Yoshito Andou ${ }^{5}$, \\ Sulaiman Man ${ }^{1,2}$, Hushairy Saidan ${ }^{3}$ and Suraiya Mahdian ${ }^{1,6}$ \\ ${ }^{1}$ Faculty of Plantation and Agrotechnology, Universiti Teknologi MARA (UiTM), Melaka Branch, Jasin Campus, \\ 77300 Merlimau, Melaka, Malaysia \\ ${ }^{2}$ Faculty of Plantation and Agrotechnology, Universiti Teknologi MARA (UiTM), Sarawak Branch, Samarahan \\ Campus, 94300 Kota Samarahan, Sarawak, Malaysia \\ ${ }^{3}$ Faculty of Chemical Engineering, Universiti Teknologi MARA (UiTM), Sarawak Branch, Samarahan Campus, \\ 94300 Kota Samarahan, Sarawak, Malaysia \\ ${ }^{4}$ Faculty of Chemical Engineering, Universiti Teknologi MARA (UiTM), 40450 Shah Alam, Selangor, Malaysia \\ ${ }^{5}$ Graduate School of Life Science and System Engineering, Kyushu Institute of Technology, Kitakyushu, \\ Fukuoka, Japan \\ ${ }^{6}$ Faculty of Plantation and Agrotechnology, Universiti Teknologi MARA (UiTM), Sarawak Branch, Mukah \\ Campus, 77300 Mukah, Sarawak, Malaysia
}

\begin{abstract}
Biochar produced from biomass with high nutrient content is essential for improving the quality of agricultural soils. An abundance of biomass is converted into biochar with high nutrient content, but studies on the conversion of pineapple and sago waste into biochar are still limited. This research aimed to produce biochar from pineapple leaf (PLB), sago bark (SBB), and sago pith (SPB) through the carbonization process with low temperature. The samples were carbonized using a laboratory electric oven at a low temperature of $350^{\circ} \mathrm{C}$. The raw biomass and biochar

ARTICLE INFO

Article history:

Received: 10 February 2020

Accepted: 13 November 2020

Published: 31 December 2020

DOI: https://doi.org/10.47836/pjst.28.S2.21

E-mail addresses:

norshidawatie1994@gmail.com (Norshidawatie Bohari)

hasmah@uitm.edu.my (Hasmah Mohidin)

juferi@uitm.edu.my (Juferi Idris)

yando@life.kyutech.ac.jp (Yoshito Andou)

sman@uitm.edu.my (Sulaiman Man)

hushairy@uitm.edu.my (Hushairy Saidan)

suraiya6551@uitm.edu.my (Suraiya Mahdian)

* Corresponding author

produced were then subjected to elemental analysis and characterization. The mineral contents of carbonized biochar such as $\mathrm{K}$, $\mathrm{N}, \mathrm{S}, \mathrm{Mg}$, and $\mathrm{Ca}$ increased from those of the feedstock concentrations. For PLP, $\mathrm{K}$ element increased 24-fold from $2.44 \pm$ $0.73 \%$ to $48.32 \pm 9.92 \%$, while $\mathrm{N}$ element increased from $6.13 \pm 2.39 \%$ to $8.33 \pm$ $5.34 \%$. However, for both SBB and SPB, $\mathrm{N}$ and $\mathrm{K}$ nutrients increased by 2 -fold. The
\end{abstract}


study reveals that pineapple leaf biochar has the potentials to be used as an alternative soil amendment to elevate soil nutrient and quality.

Keywords: Biochar, low carbonization, pineapple leaf, sago bark, sago pith residue

\section{INTRODUCTION}

With the growing in agriculture sector, the amount of agro-waste generated annually has also been increasing. Agamuthu (2009) stated that about 998 million tons of crop residues, including biomass wastes and crop fibre residues, were produced yearly, and Asia is the main contributor. Malaysia recorded more than 70 million tons of crop residues annually (Chong et al., 2014). Agricultural wastes fibers such as sago wastes and pineapple residues have contributed to a massive landfill problem and solid pollutants to the environment after harvesting. In Sarawak, sago palm (Metroxylon sagu. Rottb.) is a new emerging plantation crop, with about 43,326 hectares of sago crop are grown in large scale in Mukah (Naim et al., 2016). Their findings indicated that the highest contributor of sago wastes were residues from sago pith residues (SPW) and sago bark wastes (SBW). According to another study conducted by Chong et al. (2014), approximately $90 \%$ of the sago starch is produced in Sarawak, and sago bark is an abundant waste product from sago starch extraction.

Pineapple (Ananas comosus) is a highly nutritive, non-seasonal tropic fruit with a fine flavor. In Malaysia, pineapple is the top five fruits with the most promising demand in the local and export markets (Nazri \& Pebrian, 2017). In Sarawak, pineapple production has increased by $70 \%$ from 17 metric tonnes per hectare in 2014 to 29 metric tonnes per hectare (Edward, 2016). Sarawak is targeting 2,500 hectares by 2020, with an average production of 45 metric tons per hectare. Pineapple leaf fibre (PLF) is one of the abundantly available waste materials in Malaysia and has not been studied as required. According to Asim et al. (2015), PLF is one of the waste materials in the agriculture sector, which is widely grown in Malaysia as well as Asia. Commercially pineapple fruits are very important and leaves are considered as organic waste materials that are left behind after fruit harvesting, which is being used for producing natural fibres. The chemical composition of PLF constitutes holocellulose (70\%-82\%), lignin (5\%-12\%), and ash (1.1\%). In Malaysia, waste management of these leaves is improving time to time, whereby the leaves are collected and consigned for research and industry utilization (Padzil et al., 2020).

Pineapple residues can be categorized as a contributor to wastes because they consist of pulp, peels, stem, and leaves (Nunes et al., 2009). If these crop residues are not handled with proper disposal, it may result in bad environmental effect where the residues might inhibit the drainage system after disposal. In addition, the cost of disposal is expensive due to high transportation cost and restricted landfill for disposal activity (Upadhyay et al., 2010). 
Biochar is a carbon-rich product produced from the slow thermochemical pyrolysis of biomass materials from organic wastes such as crop residues, livestock manure, sewage sludge, and composts and then applied to soils as an amendment. Interest in biochars has recently been driven by two major global issues: climate change and the realization of the need for sustainable soil management. Biochar can be described as carbonized product after pyrolysis process which can be obtained from residues or plant biomass which highly improves soil properties and increases crop growth and soil fertility. Fu et al. (2016) indicated that the increase of pyrolysis temperature increased $\mathrm{pH}$, electrical conductivity (EC), and carbon (C) content of pineapple biochar. This proves that biochar has the potential as an additive agent to increase nutrient content and enhance its properties. Lehmann (2007) stated that all organic material added to the soil would give significant effect in increasing soil functions variety, including retention (ability to reserve nutrients) for plant growth. However, biochar holds nutrients more effectively, so there are more available nutrients compared to leaf, compost, and manure fertilizer. Biochar application into soil has the potential of increasing the $\mathrm{C}$ content, water and nutrient retention in soil (Mawardiana et al., 2013).

Due to high cellulose and lignin contents in sago bark and pineapple waste but with low commercial values, their disposal is a problem to the mills due to their large quantity. However, a few research work has been done on the conversion of these underutilized agrowastes such as pineapple waste and sago waste into biochar as an alternative soil amendment. Thus, the aim of this study is to evaluate the potential of nutrients produced by biochar from pineapple leaf, sago bark and sago pith as organic feedstocks under controlled carbonization to elevate soil nutritional status and soil quality.

\section{MATERIALS AND METHODS}

\section{Sample Preparation}

Raw PL biomass was obtained from pineapple smallholders in Kampung Melayu, Samarahan meanwhile SB and SP biomass were purchased from Sago Mill in Mukah, Sarawak. The raw biomass was washed and oven dried at $105^{\circ} \mathrm{C}$ until constant weight. Then it was crushed into fine powder and ground into a size of about $2 \mathrm{~mm}$ using a heavyduty grinder (Claoston et al., 2014).

\section{Carbonization Preparation}

Biochar production was performed according to Leng et al. (2011). Samples were placed into ceramic crucibles with fitting lids and carbonized at $350^{\circ} \mathrm{C}$ for $2 \mathrm{~h}$ in a large chamber muffle furnace (Type 62700; Thermo Scientific Barnstead/Thermolyne, USA). All biochars were then ground to pass a 1-mm sieve and kept at room temperature prior to analysis. The yield of biochar was calculated as follows: 
Biochar yield $(\%)=\frac{\text { Mass of biochar }(g)}{\text { Mass of raw material after oven dry }(g)} \times 100 \%$

\section{Analytical Methods}

Elemental analysis was carried out based on Idris et al. (2014). The main elements obtained from raw PL, SB and SP biomass, and PL, SB, and SP biochar samples were analyzed using an inductive coupled plasma-optical effluent spectrophotometer (ICP-AES, model: Perkin Elmer 2100). Approximately 1-2 g of sample was first placed in the furnace and the temperature was gradually increased to $300^{\circ} \mathrm{C}$ until smoke ceased and was subsequently raised to $500^{\circ} \mathrm{C}$. The process continued at this temperature until white or greyish-white ash was obtained. The sample was then digested using concentrated hydrochloric acid (37\% v/v) and nitric acid $(20 \% \mathrm{v} / \mathrm{v})$. pH analysis was measured using an Oakton $\mathrm{pH} 700$ Benchtop Meter (Barwant et al., 2018). For Electrical Conductivity (EC) measurement, the samples was soaked with deionized water. The ratio used was 1:5 of solid/water and agitated for 24 h. The EC was measured and recorded using a CON 700 EC meter (Eutech Instruments, USA). For the FTIR (Fourier-transform Infrared Spectroscopy) analyses, $10 \mathrm{mg}$ of the biochar was mixed with $190 \mathrm{mg}$ of spectroscopic-grade $\mathrm{KBr}$; the mixture was first hand ground and then ground in a Wig-L-bug using a stainless steel vial with a stainless steel ball pestle for $30 \mathrm{~s}$. The FTIR measurements were performed with an ATR-ThermoFisher Nicolet iS5 FTIR spectrometer. The scans were carried out in the range from 4000 to 650 $\mathrm{cm}^{-1}$ with a resolution of $4 \mathrm{~cm}^{-1}$ and 64 scans per sample. Thermogravimetric analysis (TGA) was performed using a thermogravimetric analyzer (Mettler Toledo) under air atmosphere at a heating rate of $10^{\circ} \mathrm{C} / \mathrm{min}$ from ambient temperature to $600^{\circ} \mathrm{C}$. A sample mass of $3.5 \pm 0.5 \mathrm{mg}$ was used for each analysis and the mean values were used provided that the deviations were within $5 \%$. The mass loss (TG) of the samples was represented as a function of temperature. Surface morphologies of raw and biochar of SB, SP, and PL were identified by SEM (JCM-6000, JEOL, Japan). The samples were prepared by coating with carbon at the outer layer of the sample, and then elemental components were observed under microscopy detection. X-ray diffraction (WAXD) analysis was performed using an X-ray diffractometer (MiniFlex 600, Rigaku Co., Japan) at $40 \mathrm{kV}$ and $15 \mathrm{~mA}$ at room temperature. The $\mathrm{X}$-ray initiator used was $\mathrm{Cu} \mathrm{K} \alpha$ radiation $(\lambda=1.54 \AA$ ). The diffraction angle was examined from $5^{\circ}$ to $60^{\circ}$ at a rate of $10^{\circ} / \mathrm{min}$.

\section{RESULTS AND DISCUSSION}

\section{Characteristic of Biomass}

The results for the elemental analysis of pineapple leaf, sago bark, and sago pith for raw biomass are shown in Table 1 . The basic elements, namely, primary macronutrients $(\mathrm{N}, \mathrm{P}$, 
and $\mathrm{K}$ ) and the secondary micronutrients $(\mathrm{Ca}, \mathrm{Mg}$, and $\mathrm{S}$ ) of the raw incinerated pineapple leaves were adequate and can support the initiation of any plant growth.

Table 1

Elemental compositions of raw biomass

\begin{tabular}{cccc}
\hline \multirow{2}{*}{ Element } & \multicolumn{3}{c}{ Composition (\%) } \\
\cline { 2 - 4 } & Pineapple leaf & Sago bark & Sago pith residue \\
\hline $\mathbf{C}$ & $48.4 \pm 0.27$ & $49.73 \pm 5.31$ & $49.67 \pm 6.58$ \\
$\mathbf{N}$ & $6.13 \pm 2.39$ & $4.43 \pm 3.65$ & $3.38 \pm 1.62$ \\
$\mathbf{O}$ & $41.77 \pm 2.29$ & $41.96 \pm 6.19$ & $45.92 \pm 7.63$ \\
$\mathbf{M g}$ & $0.56 \pm 0.18$ & $0.23 \pm 0.23$ & $0.24 \pm 0.13$ \\
$\mathbf{P}$ & $0.44 \pm 0.22$ & $0.11 \pm 0.24$ & $0.14 \pm 0.08$ \\
$\mathbf{S}$ & $0.14 \pm 0.03$ & $0.24 \pm 0.11$ & $0.03 \pm 0.04$ \\
$\mathbf{K}$ & $2.44 \pm 0.73$ & $2.27 \pm 1.21$ & $0.20 \pm 0.16$ \\
$\mathbf{C a}$ & $0.12 \pm 0.14$ & $1.03 \pm 0.23$ & $0.42 \pm 0.28$ \\
\hline
\end{tabular}

$\mathrm{N}$ no of repetition 30

It was observed that the raw PL and SB had high K content compared to SP. This result might be due to the naturally high $\mathrm{K}$ in pineapple leaves.

Pineapple waste is one type of organic material containing a high $\mathrm{C} / \mathrm{N}$ ratio $(50 \%-70 \%)$. Materials that have high $\mathrm{C} / \mathrm{N}$ give a greater influence to change the soil physical properties (Ridwan et al., 2018). According to Hunt et al. (2010), by converting biomass into biochar, many of its carbon content would become fixed into a more stable form. The exothermic process during the biochar production via pyrolysis precipitated carbon dioxide onto the biochar surfaces (Lehmann, 2007).

Comparing the results in Tables 1 and 2, for PLP, K element increased of 24-fold from $2.44 \pm 0.73 \%$ to $48.32 \pm 9.92 \%$, while $\mathrm{N}$ element increased from $6.13 \pm 2.39 \%$ to $8.33 \pm$ $5.34 \%$. However, for both SBB and SPB, N and K elements increased 2-fold. The highest yield of biochar was $52.00 \%$ (SBB), followed by $51.43 \%$ (PLB), and $46.48 \%$ (SPB). After carbonization at $350^{\circ} \mathrm{C}$, the differences in yield between all of them were small and insignificant comparatively. This indicates that although with low energy consumption through the oven-drying electrical source, the overall yield values were still acceptable.

It was observed that the C content in SBB and SPB increased but otherwise for PLB (Table 2) after carbonization. As pyrolysis occurred, the oxygen content of all the biomass decreased. However, the elements of $\mathrm{K}, \mathrm{Mg}$, and $\mathrm{S}$ increased in PLB and SPB compared to those in SBB. Due to the carbonization at $350^{\circ} \mathrm{C}$, the weight loss and volatile content disappeared. Hence, the nutrient content in biochar accumulated and increased after carbonization. This result is supported by Idris et al. (2014) where the utilization of biochar improved the soil fertility and reduced the use of chemical fertilizers compared 
Characteristic of elemental composition on biochar

\begin{tabular}{cccc}
\hline Properties & Pineapple leaf & Sago bark & Sago pith residue \\
\hline Yield (\%) & 51.43 & 52.00 & 46.48 \\
$\mathbf{p H}$ & 8.78 & 8.59 & 7.93 \\
$\mathbf{E C}\left(\mathbf{m S ~ c m}^{-1}\right)$ & 7.38 & 5.43 & 4.26 \\
\hline Elemental analysis & \multicolumn{3}{|}{ Composition (\%) } \\
$\mathbf{C}$ & $19.37 \pm 2.03$ & $51.36 \pm 3.58$ & $61.66 \pm 9.17$ \\
$\mathbf{N}$ & $8.33 \pm 5.34$ & $10.65 \pm 2.07$ & $6.18 \pm 5.41$ \\
$\mathbf{O}$ & $21.95 \pm 5.92$ & $33.24 \pm 0.63$ & $28.06 \pm 7.83$ \\
$\mathbf{M g}$ & $1.27 \pm 0.93$ & $0.16 \pm 0.15$ & $0.40 \pm 0.29$ \\
$\mathbf{P}$ & $0.39 \pm 0.05$ & $0.07 \pm 0.07$ & $0.18 \pm 0.17$ \\
$\mathbf{S}$ & $0.32 \pm 0.14$ & $0.07 \pm 0.09$ & $0.05 \pm 0.06$ \\
$\mathbf{K}$ & $48.32 \pm 9.92$ & $4.01 \pm 3.22$ & $0.48 \pm 0.11$ \\
$\mathbf{C a}$ & $0.05 \pm 6.33$ & $0.44 \pm 0.19$ & $2.99 \pm 1.68$ \\
\hline
\end{tabular}

to raw biomass for the same purpose with high mineral and low heavy metal contents. In addition, biochar from biomass can be used to prevent erosion and maintain soil moisture while reducing pollution to the environment (Lim \& Zaharah, 2000).

Generally, PLB, SBB, and SPB show high $\mathrm{pH}$ values. The $\mathrm{pH}$ of pineapple leaf biochar was slightly higher $(>8)$ compared to sago bark and sago pith residue biochar (Table 2). The high $\mathrm{pH}$ indicates that biochars are good soil liming materials. This finding is in agreement with that of Leng et al. (2017). The property of EC indicates a slightly higher salinity in PLB compared to those in SBB and SPB. Furthermore, higher mineral ash in biochar probably has higher electrical conductivity especially those that have high $\mathrm{K}^{+}$ion content as in PLB, due to the mobility of the $\mathrm{K}^{+}$ions (Joseph et al., 2007). As PL biochar is rich in minerals, it may be better suited as an alternative organic fertilizer and can acts as a potential soil amendment. Interestingly, among the macronutrients presence, the $\mathrm{K}$ content in PL biochar increased tremendously by 20 -fold while the K contents in SB and SP biochar increased only 2-fold. High concentrations of potassium (K) and nitrogen (N) could probably be due to the usage of fertilizers which contain potassium nitrate $\left(\mathrm{KNO}_{3}\right)$ in the commercial pineapple cultivation. Meanwhile, sago palm is mainly in its natural state condition and often left unfertilized in the mangrove swamp areas. However, there is no clear pattern for the $\mathrm{P}$ element in this study. Besides, the concentration of nutrients in the biochar also depends on the process of partial defractionation and/or devolatilization of these nutrients at elevated temperatures (Claoston et al., 2014; Hossain et al., 2011).

\section{Fourier Transform Infrared Spectroscopy (FTIR)}

Two weak peaks were observed at $2840-3000 \mathrm{~cm}^{-1}$ for PLB due to the $\mathrm{C}-\mathrm{H}$ stretching from aliphatic groups (Figure 1). The $\mathrm{C}-\mathrm{H}$ stretching of SBB and SPB between 2840-3000 
$\mathrm{cm}^{-1}$ reveals the existence of alkane groups and this finding is supported by the findings by Claoston et al. (2014) (Figures 2 and 3). The stretching vibration of the $\mathrm{C}=\mathrm{C}$ group $\left(1566-1650 \mathrm{~cm}^{-1}\right)$ was identified in the spectrum of PLB which shows the existence of cyclic alkene.

The existence of conjugated aldehyde in SBB and SPB was observed where the peak showed the $\mathrm{C}=\mathrm{O}$ stretching $\left(1685-1710 \mathrm{~cm}^{-1}\right)$. According to the FTIR spectra analysis, all the biochars exhibited the existence of the $\mathrm{C}-\mathrm{H}$ stretching, aromatic $\mathrm{C}=\mathrm{C}$ stretching, and $\mathrm{C}=\mathrm{O}$ stretching. This observation indicates that biochar began to carbonize as the temperature increased during carbonization, which suggests degradation and depolymerization of cellulose, hemicelluloses and lignin (Cantrell et al., 2012). Table 3 shows the vibration characteristics and compound class for each wavenumber. Overall, based on the FTIR spectra for biochar, carbonization at lower temperatures resulted in dehydration, beginning of bond breakage, and transformational products (Cantrell et al., 2012).

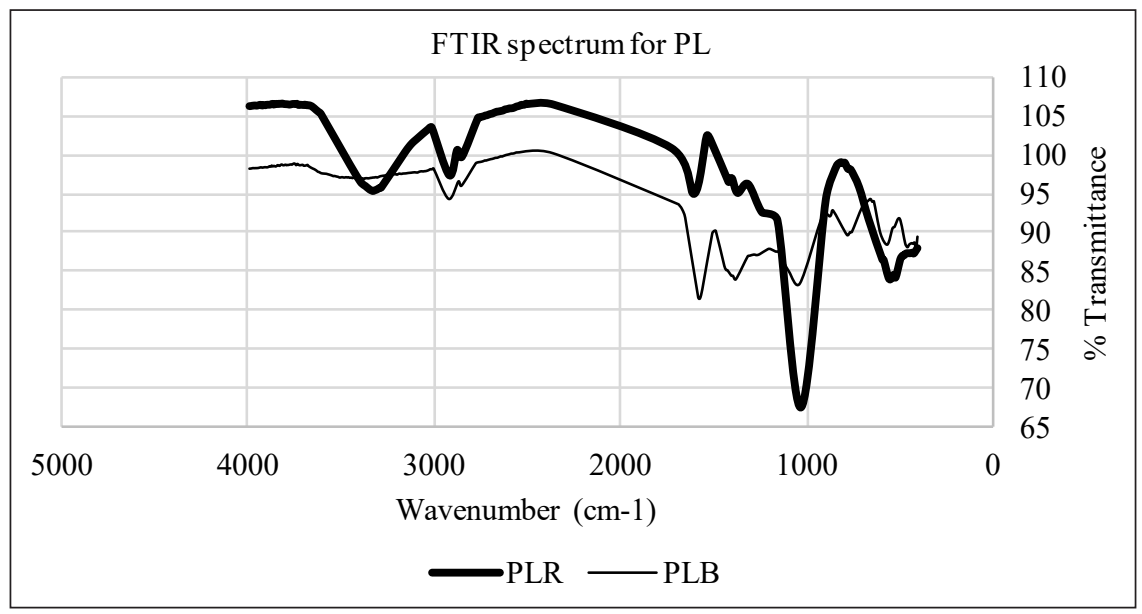

Figure 1. FTIR spectra of raw pineapple leaf (PLR) and biochar (PLB)

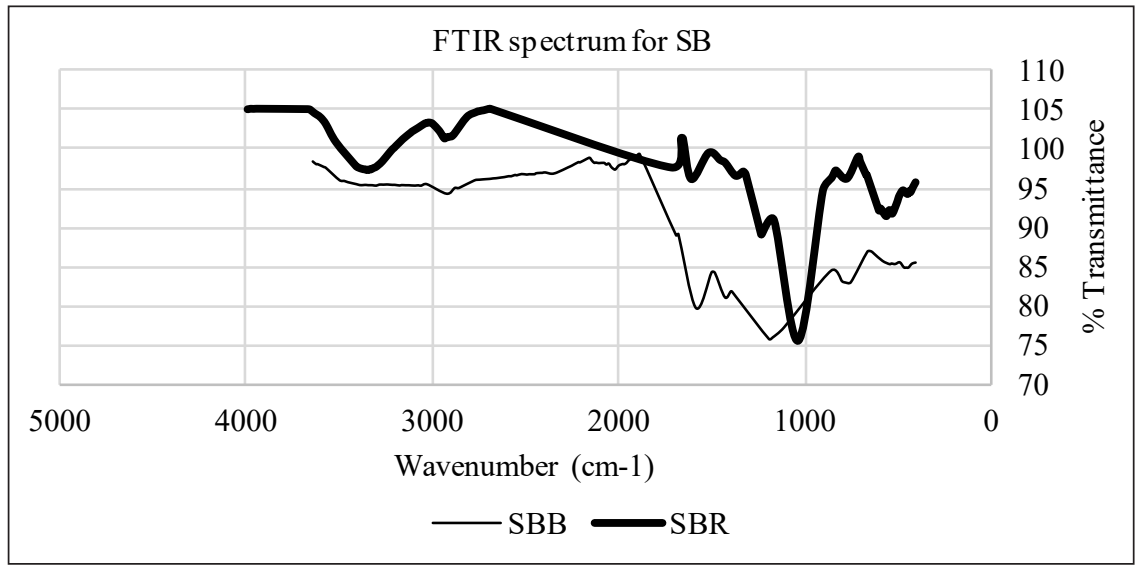

Figure 2. FTIR spectra of raw sago bark (SBR) and biochar (SBB) 


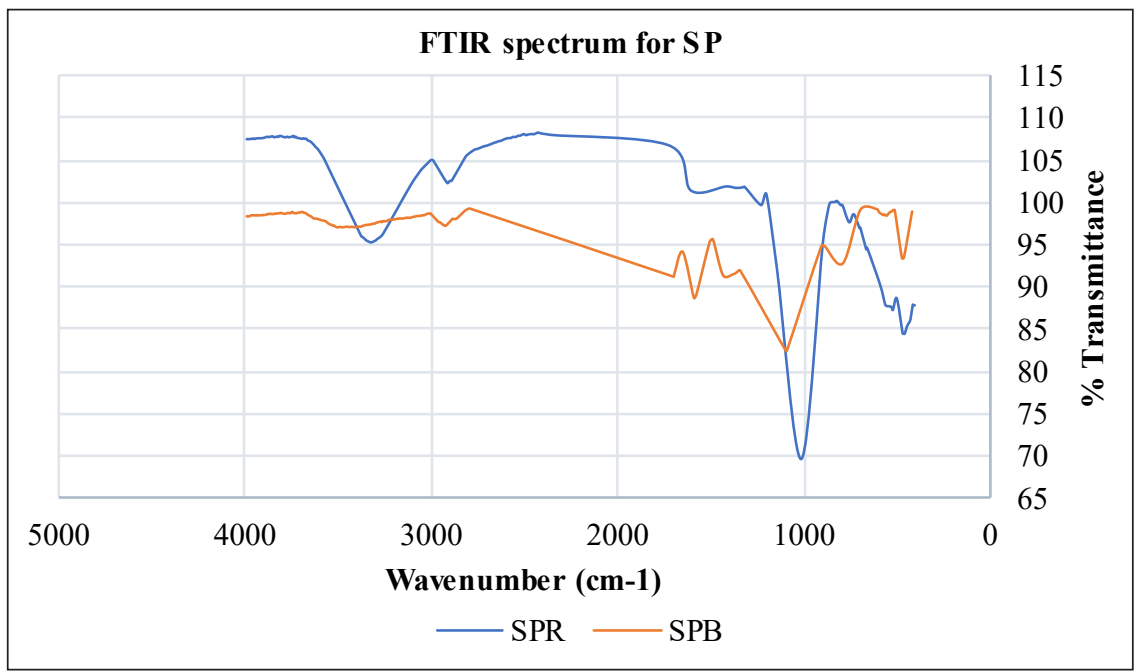

Figure 3. FTIR spectra of raw sago pith (SPR) and biochar (SPB)

Table 3

FTIR spectra of pineapple leaves and sago waste biochar

\begin{tabular}{cccccc}
\hline $\begin{array}{c}\text { Wavenumber } \\
\left(\mathbf{c m}^{-1}\right)\end{array}$ & $\begin{array}{c}\text { Pineapple } \\
\text { leaf }\end{array}$ & $\begin{array}{c}\text { Sago } \\
\text { bark }\end{array}$ & $\begin{array}{c}\text { Sago } \\
\text { pith }\end{array}$ & $\begin{array}{c}\text { Vibration } \\
\text { characteristics }\end{array}$ & Compound class \\
\hline $3000-2840$ & + & + & + & C-H stretching & Alkane \\
$1710-1685$ & - & + & + & C=O stretching & Conjugated aldehyde \\
$1650-1566$ & + & - & - & C=C stretching & Cyclic alkene \\
$1450-1390$ & - & + & + & C-H bending & Methyl group \\
$1385-1380$ & + & - & - & C-H bending & Gem dimethyl \\
$1250-1020$ & + & - & - & C-N stretching & Amine \\
$1205-1124$ & - & + & - & C-O stretching & Tertiary alcohol \\
$1124-1087$ & - & - & + & C-O stretching & Secondary alcohol \\
\hline
\end{tabular}

In this analysis, all biochar samples showed a similar thermal degradation where SPB was clearly degraded below PLB and SBB. At 10\% degradation, each sample degraded at different temperatures of $374.10,378.27$, and $364.10^{\circ} \mathrm{C}$ for PLB, SBB, and SPP, respectively (Figure 4). The result shows that SPB was easily degraded due to its characteristics where the samples lost its proportion with the increasing degradation temperature.

\section{Scanning Electron Microscopy/Energy Dispersive X-Ray Analyzer (SEM/EDX)}

The result shows that the SEM images have a large amount of pores. The pore structure of PLR was well defined and smaller compared to that of PLB (Figure 5). After carbonization, the biochar produced was observed to have large pores size exposing a variety of pore shapes and became cracked. The structure seemed to be fragile due to its thin walls and 


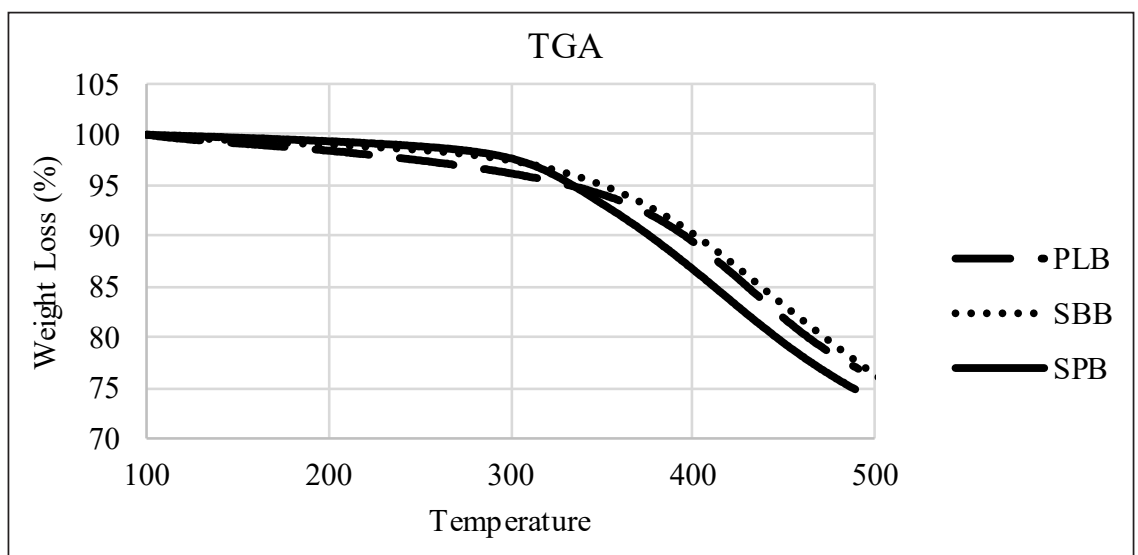

Figure 4. Thermal analysis of the biochars obtained from pineapple leaf (PLB), sago bark (SBB), and sago pith (SPB)

easily broke during pyrolysis. The surface of SBR was rough with smaller pores. After carbonization, many well-defined and softened pores were produced with large pores structure (Figure 6). This might be caused by the evolution of volatile organic compounds. Wahi et al. (2015) stated that devolatilization during pyrolysis might contribute to low denseness, improved pores formation of biochar, and higher porosities. In general, the increase in surface area at a high pyrolysis temperature is due to the removal of volatile material resulting in increased micropore volume (Ahmad et al., 2012).

Based on the outer appearance of SPR (Figure 7), the surface was smooth with many pores. After pyrolysis, biochar produced was observed to have a large pore size. This

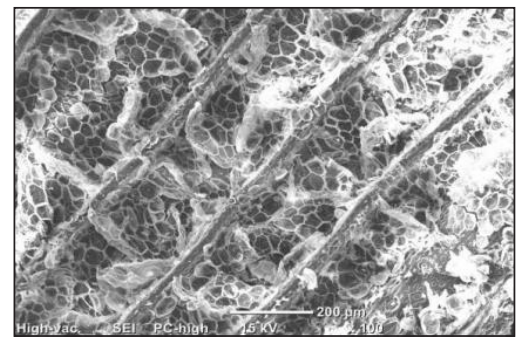

(a)

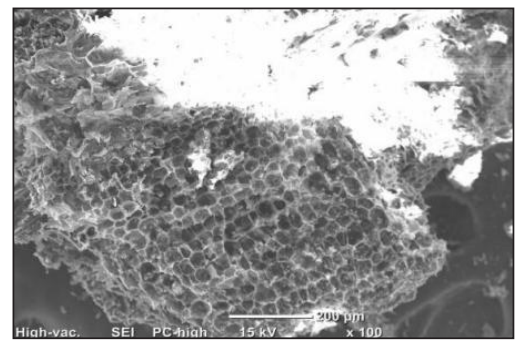

(c)

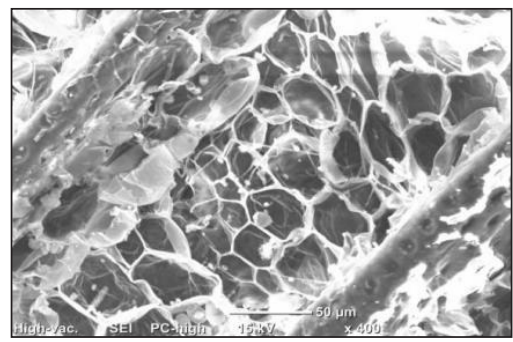

(b)

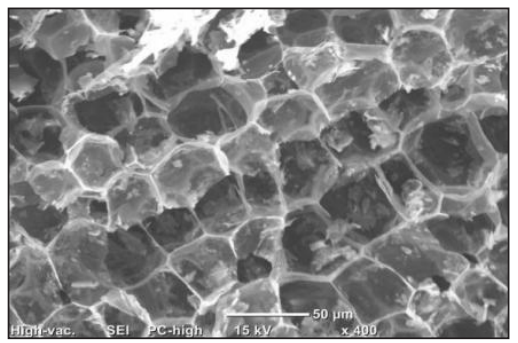

(d)

Figure 5. SEM images of raw pineapple leaf, PLR (a-b) and pineapple leaf biochar, PLB (c-d) 
indicates that the pyrolysis process was fully utilized to form porous structure of biochar (Claoston et al., 2014). Zakaria et al. (2019) stated that the pores produced could be due to the degradation of organic materials.

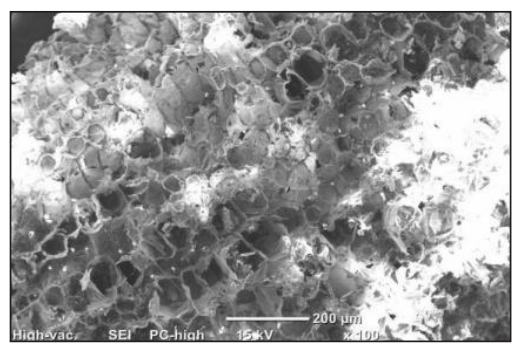

(a)

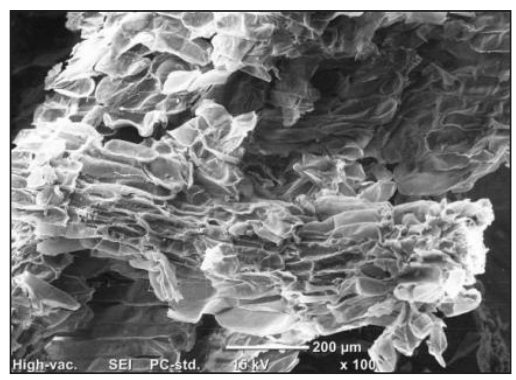

(c)

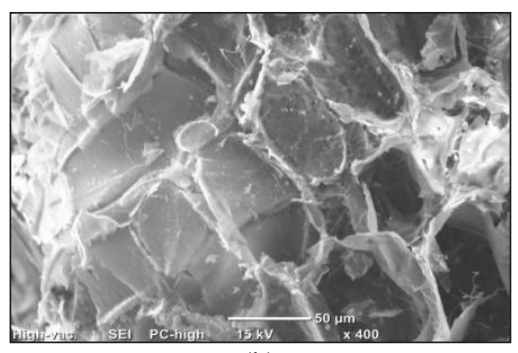

(b)

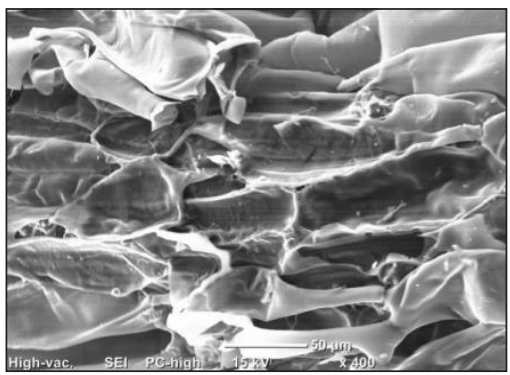

(d)

Figure 6. SEM images of raw sago pith, SPR (a-b) and sago pith biochar, SPB (c-d)

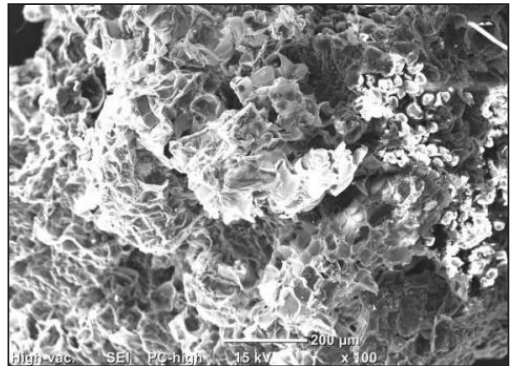

(a)

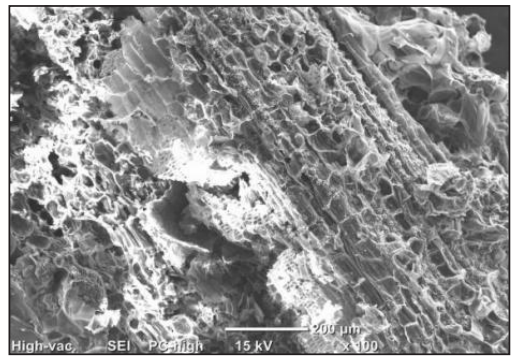

(c)

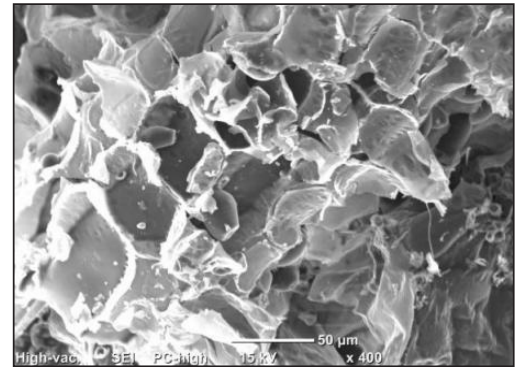

(b)

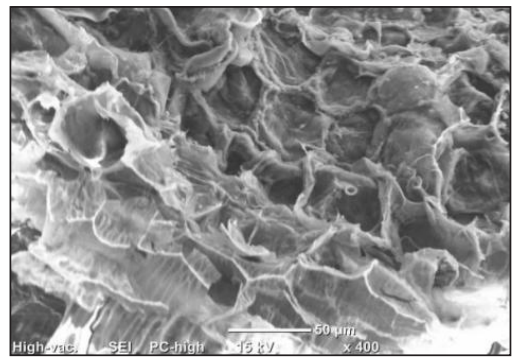

(d)

Figure 7. SEM image of raw sago pith, SPR (a-b) and sago pith biochar, SPB (c-d) 


\section{X-Ray Diffraction (XRD)}

The XRD shape of raw material is demonstrated in Figure 8. The diffractograms of SBR and PLR showed one reflection, corresponding to $2 \theta$ values of $22.06^{\circ}$ and $22.28^{\circ}$, respectively. Meanwhile, SPR showed two reflections, corresponding to $2 \theta$ values of $17.52^{\circ}$ and $22.52^{\circ}$. The narrower peaks of raw indicate the presence of cellulose structure (Shaaban et al., 2013).

Decreasing peaks at $2 \theta$ values of $21.92^{\circ}, 21.32^{\circ}$, and $21.54^{\circ}$ were observed for SBB, $\mathrm{SPB}$, and PLB, respectively (refer to Figure 9). It might be due to the decomposition of cellulose element. According to Shaaban et al. (2013), the increasing temperature during pyrolysis may cause the peaks of stipulated angles disappear, and cellulose starts to decompose.

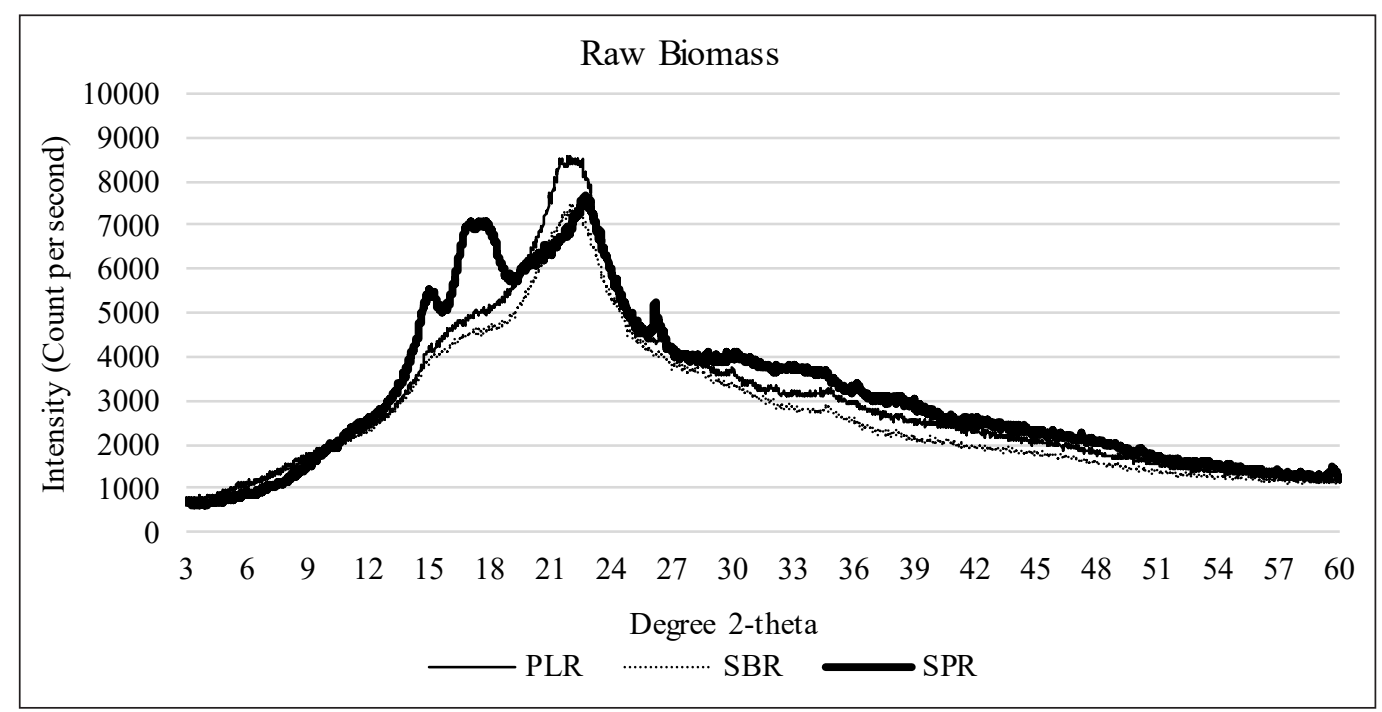

Figure 8. XRD patterns of raw pineapple leaf (PLR), sago bark (SBR), and sago pith (SPR)

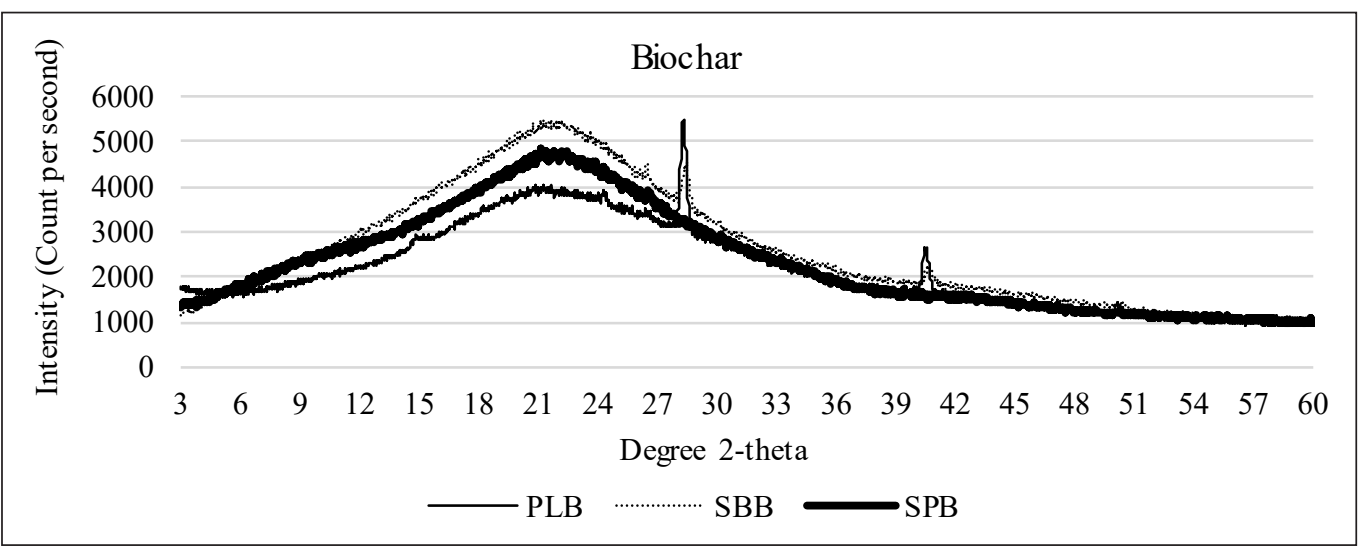

Figure 9. XRD patterns of pineapple leaf (PLB), sago bark (SBB), and sago pith (SPB) biochar 
The elemental analysis showed the highest nutrient content in PLB compared to SBB and SPB. PLB has the highest nutrient content of Mg, S, and K. SEM micrographs indicate the best development of pores in PLB compared to those in SBB and SPB, and the results are comparable with other studies. The plant growth in terms of root growth and photosynthesis capacity requires high macronutrients. It can be concluded that the pineapple leaf biochar can be the most suitable additive to be applied to the soil to elevate soil nutritional status and quality.

\section{CONCLUSION}

The production of biochar from underutilized pineapple leaf and sago waste was successfully determined using simple carbonization at low temperature. This study showed all minerals (i.e., $\mathrm{P}, \mathrm{K}, \mathrm{Mg}, \mathrm{Ca}$ ) increased from their initial concentrations in the feedstock. The minerals contents in carbonized biochar such as $\mathrm{K}, \mathrm{N}, \mathrm{S}, \mathrm{Mg}$, and $\mathrm{Ca}$ also increased. For PLP, K element increased 24-fold from $2.44 \pm 0.73 \%$ to $48.32 \pm 9.92 \%$, while N element increased from $6.13 \pm 2.39 \%$ to $8.33 \pm 5.34 \%$. However, for SBB and SPB, N and $\mathrm{K}$ nutrients only increased 2-fold. SEM micrographs indicate the best development of pores in PLB compared to those in SBB and SPB, and the results are comparable with other studies. The overall results on biochar obtained from pineapple leaves, sago bark, and sago pith residues, indicate the potential of inherent nutrient content in PLB, SBB and SPB to be used as an alternative soil amendment. However, future work needs to be done to quantify the essential nutrients generated to make further recommendations. This study showed that the underutilized pineapple leaf biochar could potentially be used as an alternative to elevate soil nutritional status and to mitigate environmental problems.

\section{ACKNOWLEDGEMENT}

The authors are grateful to Universiti Teknologi MARA, Malaysia, UiTM Sarawak Branch, Samarahan Campus, UiTM Melaka Branch, Jasin Campus, and Kyushu Institute of Technology, Japan for the financial and technical support in this study.

\section{REFERENCES}

Agamuthu, P., (2009). Challenges and opportunities in agro-waste management: An Asian perspective. Retrieved September 20, 2018, from http://www.env.go.jp/recycle/3r/en/forum_asia/results/pdf/20091111/08.pdf

Ahmad, M., Lee, S. S., Dou, X., Mohan, D., Sung, J. K., Yang, J. E., \& Ok, Y. S. (2012). Effects of pyrolysis temperature on soybean stover-and peanut shell-derived biochar properties and TCE adsorption in water. Bioresource Technology, 118, 536-544. doi:10.1016/j.biortech.2012.05.042

Asim, M., Abdan, K., Jawaid, M., Nasir, M., Dashtizadeh, Z., Ishak, M. R., \& Hoque, M. E. (2015). A review on pineapple leaves fibre and its composites. International Journal of Polymer Science, 2015 1-16. doi:10.1155/2015/950567 
Cantrell, K. B., Hunt, P. G., Uchimiya, M., Novak, J. M., \& Ro, K. S. (2012). Impact of pyrolysis temperature and manure source on physicochemical characteristics of biochar. Bioresource Technology, 107, 419-428. doi:10.1016/j.biortech.2011.11.084

Chong, K. H., Law, P. L., Rigit, A. R. H., Baini, R., \& Shanti, F. S. (2014). Sago bark as renewable energy. Journal of Civil Engineering, Science and Technology, 5(2), 29-34. doi:10.33736/jcest.136.2014

Claoston, N., Samsuri, A. W., Ahmad Husni, M. H., \& Mohd Amran, M. S., (2014). Effects of pyrolysis temperature on physicochemical properties of empty fruit bunch and rice husk biochars. Waste Management and Research, 32(4), 331-339. doi:10.1177/0734242x14525822

Edward, C. (2016, August 14). Pineapple planters all excited about MD2. Borneo Post. Retrieved June 23, 2020, from https://www.theborneopost.com/2016/08/14/pineapple-planters-all-excited-about-md2/

Fu, B., Ge, C, Yue, L., Luo, J., Feng, D., Deng, H., \& Yu, H. (2016). Characterization of biochar derived from pineapple peel waste and its application for sorption of oxytetracycline from aqueous solution. BioResources, 11(4), 9017-9035. doi:10.15376/biores.11.4.9017-9035

Hossain, M. K., Strezov, V., Chan, K. Y., Ziolkowski, A., \& Nelson, P. F. (2011). Influence of pyrolysis temperature on production and nutrient properties of wastewater sludge biochar. Journal of Environmental Management, 92(1), 223-228. doi:10.1016/j.jenvman.2010.09.008

Hunt, J., DuPonte, M., Sato, D., \& Kawabata, A. (2010). The basics of biochar: A natural soil amendment. Soil and Crop Management (SCM-30). Retrieved September 20, 2018, from http://www.ctahr.hawaii. edu/oc/freepubs/pdf/SCM-30.pdf

Idris, J., Shirai, Y., Ando, Y., Ali, A. A. M., Othman, M. R., Ibrahim, I., \& Hassan, M. A. (2014). Production of biochar with high mineral content from oil palm biomass. Malaysian Journal of Analytical Sciences, 18(3), 700-704.

Joseph, S. D., Downie, A., Munroe, P., Crosky, A., \& Lehmann, J. (2007, December 9-11). Biochar for carbon sequestration, reduction of greenhouse gas emissions and enhancement of soil fertility; A review of the materials science. In Proceedings of the Australian combustion symposium (pp. 130-133). Sydney, Australia.

Lehmann, J. (2007). Bio-energy in the black. Frontiers in Ecology and the Environment, 5(7), 381-387. doi:10.1890/1540-9295(2007)5[381:bitb]2.0.co;2

Leng, L. Y., Husni, M. H. A., \& Samsuri, A. W., (2011). Comparison of the carbon-sequestering abilities of pineapple leaf residue chars produced by controlled combustion and by field burning. Bioresource Technology, 102(22), 10759-10762. doi:10.1016/j.biortech.2011.08.131

Lim, K. C., \& Zaharah, A. R. (2000). Decomposition and N \& K release by oil palm empty fruit bunches applied under mature palms. Journal of Oil Palm Research, 12(2), 55-62.

Mawardiana, Sufardi., \& Husen E. (2013). Pengaruh residu biochar dan pemupukan NPK terhadap sifat kimia tanah dan pertumbuhan serta hasil tanaman padi (Oryza sativa L.) musim tanam ketiga [Residual effect of biochar and NPK fertilization toward the dynamics of nitrogen, soil chemical properties and rice crop in third season planting]. Jurnal Manajemen Sumber Dayalahan, 2(3), 255-260. 
Naim, H. M., Yaakub, A. N., \& Hamdan, D. A. A. (2016). Commercialization of sago through estate plantation scheme in Sarawak: The way forward. International Journal of Agronomy, 2016, 1-6. doi:10.1155/2016/8319542

Nazri, A. M., \& Pebrian, D. E. (2017). Analysis of energy consumption in pineapple cultivation in Malaysia: A case study. Pertanika Journal of Science \& Technology, 25(1), 17-28.

Nunes, M. C. N., Emond, J. P., Rauth, M., Dea, S., \& Chau, K. V., (2009). Environmental conditions encountered during typical consumer retail display affect fruit and vegetable quality and waste. Postharvest Biology and Technology, 51(2), 232-241. doi:.1016/j.postharvbio.2008.07.016

Padzil, F. N. M., Ainun, Z. M. A., Kassim, N. A., Lee, S. H., Lee, C. H., Ariffin, H., \& Zainudin, E. S. (2020). Chemical, physical and biological treatments of pineapple leaf fibres. In M. Jawaid, M. Asim, P. Tahir \& M. Nasir (Eds.), Pineapple leaf fibers (pp. 73-90). Singapore: Springer

Ridwan, I., Jaya, A. M., \& Mantja, K. (2018). Pengembangan bioindustri kompos limbah pertanian melalui pemberdayaan masyarakat pesisir di Kecamatan Labakkang [Development of Agricultural Waste Compost Bioindustry through Empowerment of Coastal Communities in Labakkang District]. Jurnal Dinamika Pengabdian (JDP), 3(2), 165-176. doi:10.20956/jdp.v3i2.4248

Shaaban, A., Se, S., Mitan, N. M. M., \& Dimina, M. F. (2013). Characterization of biochar derived from rubber wood sawdust through slow pyrolysis on surface porosities and functional groups. Procedia Engineering, 68, 365-371. doi:10.1016/j.proeng.2013.12.193

Upadhyay, A., Lama, J. P., \& Tawata, S. (2010). Utilization of pineapple waste. Journal of Food Science and Technology Nepal, 6, 10-18. doi:10.3126/jfstn.v6i0.8255

Wahi, R., Aziz, S. M. A., Hamdan, S., \& Ngaini, Z. (2015, December 14-16). Biochar production from agricultural wastes via low-temperature microwave carbonization. In IEEE International RF and Microwave Conference (RFM) (pp. 244-247). Kuching, Malaysia.

Zakaria, Z. A., Boopathy, R., Dib, J. R. (2019). Valorisation of agro-industrial residues-volume I: Biological approaches. Cham, Switzerland: Springer Nature AG. 